\title{
Influence of internal pore architecture on biological and mechanical properties of three-dimensional fiber deposited scaffolds for bone regeneration
}

Citation for published version (APA):

Ostrowska, B., Di Luca, A., Moroni, L., \& Swieszkowski, W. (2016). Influence of internal pore architecture on biological and mechanical properties of three-dimensional fiber deposited scaffolds for bone regeneration. Journal of Biomedical Materials Research Part A, 104(4), 991-1001. https://doi.org/10.1002/jbm.a.35637

Document status and date:

Published: 01/04/2016

DOI:

10.1002/jbm.a.35637

Document Version:

Publisher's PDF, also known as Version of record

\section{Document license:}

Taverne

Please check the document version of this publication:

- A submitted manuscript is the version of the article upon submission and before peer-review. There can be important differences between the submitted version and the official published version of record.

People interested in the research are advised to contact the author for the final version of the publication, or visit the DOI to the publisher's website.

- The final author version and the galley proof are versions of the publication after peer review.

- The final published version features the final layout of the paper including the volume, issue and page numbers.

Link to publication

\footnotetext{
General rights rights.

- You may freely distribute the URL identifying the publication in the public portal. please follow below link for the End User Agreement:

www.umlib.nl/taverne-license

Take down policy

If you believe that this document breaches copyright please contact us at:

repository@maastrichtuniversity.nl

providing details and we will investigate your claim.
}

Copyright and moral rights for the publications made accessible in the public portal are retained by the authors and/or other copyright owners and it is a condition of accessing publications that users recognise and abide by the legal requirements associated with these

- Users may download and print one copy of any publication from the public portal for the purpose of private study or research.

- You may not further distribute the material or use it for any profit-making activity or commercial gain

If the publication is distributed under the terms of Article 25fa of the Dutch Copyright Act, indicated by the "Taverne" license above, 


\title{
Influence of internal pore architecture on biological and mechanical properties of three-dimensional fiber deposited scaffolds for bone regeneration
}

\author{
Barbara Ostrowska, ${ }^{1,2}$ Andrea Di Luca, ${ }^{2}$ Lorenzo Moroni, ${ }^{2,3}$ Wojciech Swieszkowski ${ }^{1}$ \\ ${ }^{1}$ Materials Design Division, Faculty of Material Science and Engineering, Warsaw University of Technology, 141 Woloska \\ Street, Warsaw 02-507, Poland \\ ${ }^{2}$ Tissue Regeneration Department, University of Twente, Drienerlolaan 5, 7522 NB Enschede, The Netherlands \\ ${ }^{3}$ Complex Tissue Regeneration Department, MERLN Institute for Technology Inspired Regenerative Medicine, Maastricht \\ University, Universiteitsingel 40, 6229 ER Maastricht, The Netherlands
}

Received 16 April 2015; revised 12 December 2015; accepted 21 December 2015

Published online 22 January 2016 in Wiley Online Library (wileyonlinelibrary.com). DOI: 10.1002/jbm.a.35637

\begin{abstract}
Fused deposition modeling has been used to fabricate three-dimensional (3D) scaffolds for tissue engineering applications, because it allows to tailor their pore network. Despite the proven flexibility in doing so, a limited amount of studies have been performed to evaluate whether specific pore shapes have an influence on cell activity and tissue formation. Our study aimed at investigating the influence of internal pore architecture on the biological and mechanical properties of $3 \mathrm{D}$ scaffolds seeded with mesenchymal stromal cells. Polycaprolactone scaffolds with six different geometries were fabricated. The 3D samples were manufactured with different lay-down pattern of the fibers by varying the layer deposition angle from $0^{\circ} / 15^{\circ} / 30^{\circ}$, to $0^{\circ} / 30^{\circ} / 60^{\circ}, 0^{\circ} / 45^{\circ} / 90^{\circ}, 0^{\circ} / 60^{\circ} / 120^{\circ}, 0^{\circ} / 75^{\circ} / 150^{\circ}$, and $0^{\circ} / 90^{\circ} / 180^{\circ}$. The scaffolds were investigated by scanning electron microscopy and micro computed tomographical analysis and displayed a fully interconnected pore network. Cell prolif-
\end{abstract}

eration and differentiation toward the osteogenic lineage were evaluated by DNA, alkaline phosphatase activity, and polymerase chain reaction. The obtained scaffolds had structures with open porosity $(50 \%-60 \%)$ and interconnected pores ranging from 380 to $400 \mu \mathrm{m}$. Changing the angle deposition affected significantly the mechanical properties of the scaffolds. With increasing the angle deposition between successive layers, the elastic modulus increased as well. Cellular studies also showed influence of the internal architecture on cell adhesion and proliferation within the 3D construct, yet limited influence on cell differentiation was observed. (c) 2016 Wiley Periodicals, Inc. J Biomed Mater Res Part A: 104A: 991-1001, 2016.

Key Words: fused deposition modeling, polycaprolactone, scaffolds, tissue engineering, mesenchymal stromal cells, mechanical properties

How to cite this article: Ostrowska B, Di Luca A, Moroni L, Swieszkowski W. 2016. Influence of internal pore architecture on biological and mechanical properties of three-dimensional fiber deposited scaffolds for bone regeneration. J Biomed Mater Res Part A 2016:104A:991-1001.

\section{INTRODUCTION}

Most tissue engineering strategies used for the regeneration of functional tissues rely on the application of threedimensional (3D) scaffolds that guide the proliferation and differentiation of seeded cells in vitro and in vivo. A suitable scaffold should have a proper porosity and pore size to allow for cell proliferation and tissue formation, as well as mechanical properties matching those of the tissues to be regenerated and provide a structurally functional support at the implant site. ${ }^{1}$ Interconnected porosity is required to maintain cell viability and allow the culture media to flow in order to ensure continuous supply of nutrients, metabolites, waste products removal, and extracellular matrix (ECM) deposition. ${ }^{2-9}$

There are several fabrication methods currently used for the creation of 3D scaffolds with high porosity and interconnected pores. ${ }^{1,10-14}$ Fused deposition modeling (FDM) is one of the most interesting scaffold fabrication methods, since it allows manufacturing scaffolds with controllable geometrical parameters, good mechanical properties, and biocompatibility. Furthermore, scaffolds with predesigned external geometry and internal architecture as well as

Correspondence to: W. Swieszkowski; e-mail: wswieszk@inmat.pw.edu.pl

Contract grant sponsor: European Union in the framework of European Social Fund through the Warsaw University of Technology Development Programme, realized by Center of Advanced Studies and by the European Cooperation in Science and Technology COST Action MP1005 (NAMABIO)

Contract grant sponsor: European Regional Development Fund within the Innovative Operational Program in the frame of project BIO-IMPLANT; contract grant number: POIG.01.01.02-00-022/09

Contract grant sponsor: Poland-Norwegian project NewJoint; contract grant number: Pol-Nor/202132/68/2013

Contract grant sponsor: Dutch Technology Foundation; contract grant number: 11135 
required stiffness, strength, and biological properties can be generated. ${ }^{2,15-17}$ The production of scaffolds with proper internal architecture satisfying individual requirements of each patient is a key feature of FDM. ${ }^{18}$

The role of 3D scaffolds is to provide the physical, chemical, and biological cues to organize, repair, and encourage the appropriate cell and tissue morphogenesis for the regeneration of functional tissue. As our understanding of the importance of a 3D environment on cell behavior progresses, researchers continue to improve on scaffolds designs to achieve greater control over tissue regeneration. ${ }^{19,20}$

The mechanical strength of an implant is directly connected with the internal architecture of the scaffold and has to be tailored according to the different implant applications. ${ }^{21-24}$ In the last decade, the use of scaffolds for tissue regeneration gained a lot of interest as possible application beside the operation theatre. Therefore, FDM scaffolds with different deposition pattern of the fibers were investigated in this article to evaluate the influence of internal scaffold architecture on mechanical and biological properties. This could help in the future optimal fiber lay-down orientation.

Our approach was to fabricate polycaprolactone (PCL) scaffolds with different internal architectures, but with similar fiber dimension and surface to volume ratio. By varying the fiber lay-down orientation, scaffolds with different pore size and shape and fiber connections were manufactured. The static and dynamic mechanical properties of the scaffolds were investigated to assess how the internal architecture influences mechanical properties. The ability to provide a proper mechanical support for tissue ingrowth is one of the major requirements for tissue engineered scaffolds that determines its application as a material for target tissue regeneration. ${ }^{10,25-27}$ Finally, scaffolds with different pore network architecture were evaluated for bone tissue engineering applications, by assessing the adhesion, proliferation, and differentiation potential of human mesenchymal stromal cells (hMSCs).

\section{EXPERIMENTAL}

\section{Material}

Polycaprolactone (PCL) (Sigma-Aldrich, St. Louis, MO) with a molecular weight $(\mathrm{Mn})$ of $89 \mathrm{kDa}$, a melt index of $0.95 \mathrm{~g} /$ $10 \mathrm{~min}$ at $95^{\circ} \mathrm{C}$ (ISO1133), a melting temperature of $57^{\circ} \mathrm{C}$, and a glass-transition temperature of $-60^{\circ} \mathrm{C}$ was used for this study.

\section{Material characterization}

Gel permeation chromatography was used to determine the molecular mass of PCL samples using an Agilent 1200 series system. PCL dry samples were dissolved in chloroform $(0.2 \% \mathrm{w} / \mathrm{v})$. The injection volume was $60 \mu \mathrm{L}$. The molecular weight of PCL sample was $89 \mathrm{kDa}$.

Differential scanning calorimetry (TA Instruments Q2000; TA Instruments, New Castle, DE) was used to analyze the thermal properties of PCL. Thermal analysis was performed in the temperature range of $-100^{\circ} \mathrm{C}$ to $+150^{\circ} \mathrm{C}$, at a heating rate of $10^{\circ} \mathrm{C} / \mathrm{min}$, under an $\mathrm{N}_{2}$ flow of $20 \mathrm{~mL} / \mathrm{min}$. The meas- ured glass transition temperature $\left(T_{\mathrm{g}}\right)$ and melting temperature $\left(T_{\mathrm{m}}\right)$ were $-60^{\circ} \mathrm{C}$ and $57^{\circ} \mathrm{C}$, respectively.

\section{Fabrication of the scaffolds}

Cylindrical scaffolds $(6 \mathrm{~mm}$ in diameter and $4 \mathrm{~mm}$ in height) with 3D orthogonal periodic porous architectures were designed using Solid Works 3D CAD Design Software. The geometrical model of the scaffold was then exported to a Bioscaffolder ${ }^{\circledR}$ machine (SYSENG, Germany) as an STL file. Scaffolds with six different lay-down patterns, namely $0^{\circ}$ / $15^{\circ} / 30^{\circ}, 0^{\circ} / 30^{\circ} / 60^{\circ}, 0^{\circ} / 45^{\circ} / 90^{\circ}, 0^{\circ} / 60^{\circ} / 120^{\circ}, 0^{\circ} / 75^{\circ} / 150^{\circ}$, and $0^{\circ} / 90^{\circ} / 180^{\circ}$, were fabricated. Briefly, PCL granules were placed in a stainless steel reservoir and heated at $T=95^{\circ} \mathrm{C}$ through a heated cartridge unit. After a molten phase was reached, a nitrogen pressure of 5 bar was applied to the reservoir to transfer the molten polymer to an endless extrusion screw jacket. The extrusion screw had a spindle speed of $125 \mathrm{rpm}$. The material was then extruded through a $330-\mu \mathrm{m}$ needle on a base plate with a deposition speed of $95 \mathrm{~mm} / \mathrm{min}$. The layer-by-layer plotted fibrous scaffolds were characterized by theoretical parameters like spacing between fibers in the same layer $(510 \mu \mathrm{m})$, layer thickness $(220 \mu \mathrm{m})$, and the configuration of the deposited fibers by varying the layer deposition angle [Fig. $1(\mathrm{a})]$.

\section{Scaffold characterization}

The morphology of scaffolds was studied using scanning electron microscopy (SEM, SU8000 HITAHI). Samples were gold sputter coated (Leica EM SCD 500) before SEM analysis. The fibers diameters, distance between the fibers, and layer thickness were measured from the SEM micrographs on 50 randomly selected fibers using Image Analysis Software (ImageJ, National Institutes of Health, Bethesda, MD). The 3D structure and internal architecture were also investigated by micro computed tomographical analysis $(\mu \mathrm{CT}$; SkyScan 1172). The $\mu$ CT scanner was set to a voltage of 59 $\mathrm{kV}$ and current of $167 \mu \mathrm{A}$. A scanning time of 14.5 min was needed for each sample. An isotropic voxel size of $10 \mu \mathrm{m}$ was achieved in the reconstructed slices. 3D models of the scaffolds were generated based on $\mu \mathrm{CT}$ scans. Scaffolds porosities were determined using the Analyzer Bruker software. The porosity was also calculated theoretically, following the approach of Landers et $\mathrm{al}^{2}$ :

$$
P=1-\frac{V_{\text {scaffold }}}{V_{\text {cube }}}=1-\frac{M}{V}=1-\frac{\pi \cdot d_{1}{ }^{2}}{4 \cdot d_{2} \cdot d_{3}}
$$

where, $P$ is the scaffold porosity, $M$ the scaffold mass, $V$ the scaffold volume, $d_{1}$ the fiber diameter, $d_{2}$ the fiber spacing, and $d_{3}$ the layer thickness [Fig. 1(b)].

\section{Samples sterilization}

The 3D scaffolds were sterilized by gamma-radiation (cobalt source $6.26 \mathrm{kGy} / \mathrm{h}$ ) in atmospheric air, at a constant temperature of $28^{\circ} \mathrm{C}$. All samples were sterilized using a standard sterilization dose of $25 \mathrm{kGy}$. 

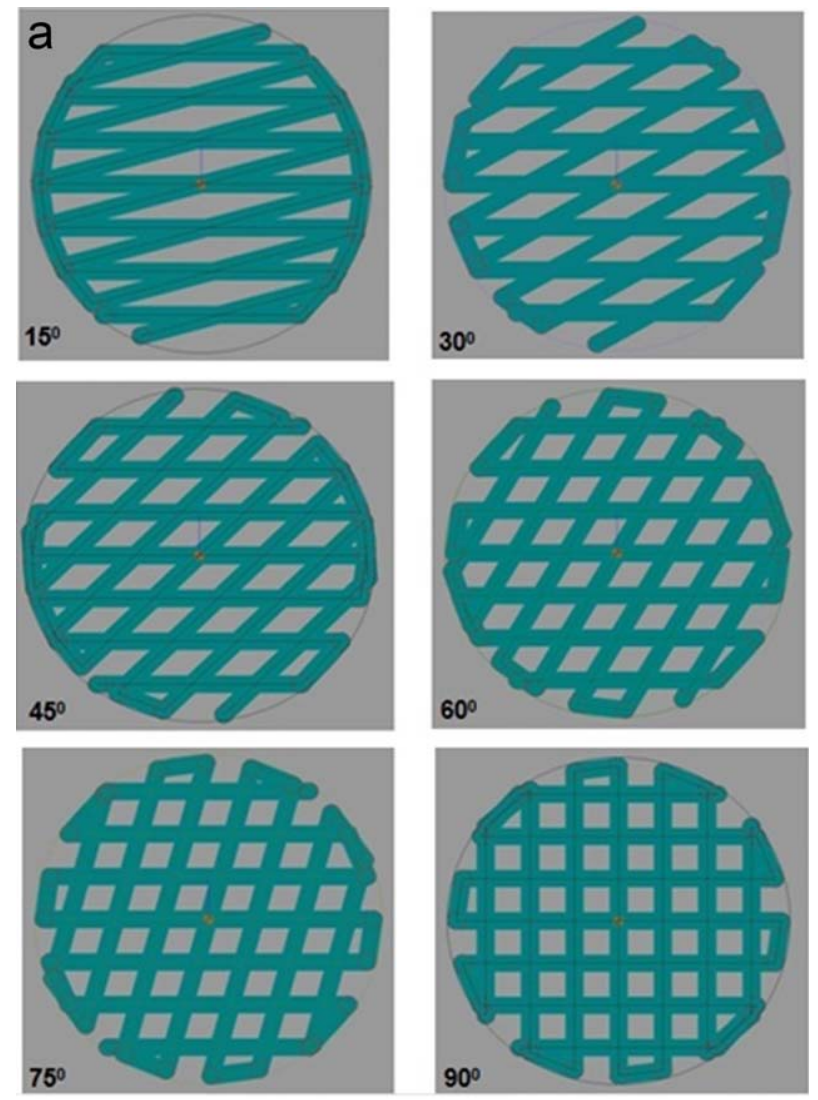

b

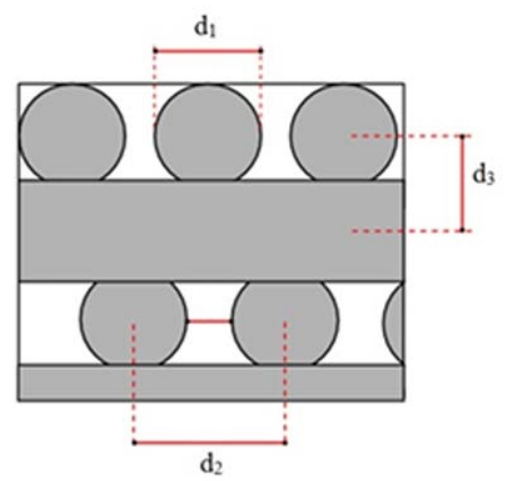

FIGURE 1. Models of the scaffolds (a) with different lay-down pattern configurations; PrimCAM view and scaffold scheme (b) where $d_{1}$ is the fiber diameter, $d_{2}$ the fiber spacing, and $d_{3}$ the layer thickness.

\section{Mechanical investigation}

Mechanical properties of scaffolds with six different laydown patterns were evaluated and compared between each other. The 3D samples were characterized in two directions: compression (z-direction) and rotational ( $x / y$-direction).

Compression test. Compression tests of the samples were carried out using a Zwick tester (Zwick Z005) at a crosshead speed of $1 \mathrm{~mm} / \mathrm{min}$, up to $20 \%$ of compressive strain. The apparent elastic modulus was calculated from the initial linear region of the stress-strain curves as reported in ASTM standard D1621-04a "Compressive properties of rigid cellular plastics" and other publications presenting mechanical behavior of PCL scaffolds. ${ }^{21,28,29}$ Since the linear stage of the compression curve was not obvious, the apparent compressive modulus was determined as the slope of the tangent to the curve with an intercept of strain.

Dynamic mechanical analysis. 3D scaffolds mechanical response was also assessed in dynamic mechanical conditions, since this can more closely simulate the physiological environment. Moreover, this enables the characterization of scaffold's viscoelastic properties. Dynamic mechanical properties have been tested using a rotational rheometer with controlled strain SMT, ARES (TA Instruments). The test was carried out on rectangular samples $\left(50 \times 10 \times 3 \mathrm{~mm}^{3}\right)$ at a temperature of $37^{\circ} \mathrm{C}$, and with a constant strain of $0.5 \%$. In the dynamic test, a rotational rheometer was used to twist the samples. Tested scaffolds were loaded with frequency ranging from 0.1 to $100 \mathrm{~Hz}$. The ability of the scaffolds to store energy was calculated by measuring the elastic (storage) modulus $E^{\prime}$ using Eq. (2).

$$
E^{\prime}=\left(\frac{\sigma}{\gamma}\right) \cos \delta
$$

where, $\delta$ is the phase angle, $\sigma$ the stress, and $\gamma$ the strain.

\section{Cell-scaffold interactions studies}

Cell culture and seeding. hMSCs were cultured in MSC proliferation medium in a $300-\mathrm{cm}^{2}$ cell culture flask in a $5 \%$ $\mathrm{CO}_{2}$ humidified incubator at $37^{\circ} \mathrm{C}$, until $70 \%$ confluence. Using trypsin-EDTA, the cells were detached from the flask and seeded at a density of $5 \times 10^{5}$ in $40 \mu \mathrm{L}$ of medium. After $4 \mathrm{~h}$, the proliferation medium, which contains $\alpha$-MEM (Invitrogen, Carlsbad, CA) supplemented with 10\% fetal bovine serum (Sigma-Aldrich), $1 \mathrm{ng} / \mathrm{mL}$ basic fibroblast growth factor (Instruchemie, The Netherlands), $0.2 \mathrm{mM}$ ascorbic acid (Invitrogen), 100 units/mL penicillin (Invitrogen), and $10 \mu \mathrm{g} / \mathrm{L}$ streptomycin (Invitrogen), was added (700 $\mu \mathrm{L}$ per well). The hMSCs were cultured on PCL scaffolds for 7 days in proliferation medium. Medium was refreshed every 2 days. At day 7, the proliferation media was changed and the cells within the scaffolds were cultured for another 1 and 28 days in basic and mineralization media. Basic media consisted of proliferation media without basic fibroblast growth factor. Mineralization media consisted of basic media supplemented with $10 \mathrm{n} M$ dexamethasone (Sigma-Aldrich) and $10 \mathrm{~m} M \quad \beta$-glycerol-phosphate (Sigma-Aldrich).

Biochemical analysis. The evaluation of the cell seeding efficiency was performed after $8 \mathrm{~h}$ of culture using DNA assay. DNA and alkaline phosphatase (ALP) assays were performed after 1 and 28 days of incubation in differentiation medium. Quantification of total DNA was done with Cyquant dye kit according to the manufacturer's description (Molecular Probes, Eugene, OR) using a spectrofluorometer (LS 50B, Perkin Elmer, Waltham, MA). ALP activity was determined using a spectrofluorometer (LS 50B, Perkin Elmer) after 
TABLE I. Fiber diameters, distance between the fibers and layer thickness measured from the SEM micrographs.

\begin{tabular}{|c|c|c|c|c|c|c|}
\hline & \multicolumn{6}{|c|}{ Angle Deposition } \\
\hline & $15^{\circ} / 30^{\circ}$ & $30^{\circ} / 60^{\circ}$ & $45^{\circ} / 90^{\circ}$ & $60^{\circ} / 120^{\circ}$ & $75^{\circ} / 150^{\circ}$ & $90^{\circ} / 180^{\circ}$ \\
\hline \multicolumn{7}{|c|}{ Fiber diameter $(\mu \mathrm{m})$} \\
\hline Theoretical & \multicolumn{6}{|c|}{330} \\
\hline Experimental & $307.0( \pm 19.0)$ & $312( \pm 11.5)$ & $319.6( \pm 20.1)$ & $300.6( \pm 24.8)$ & $318.1( \pm 17.3)$ & $313.8( \pm 9.6)$ \\
\hline \multicolumn{7}{|c|}{ Distance between fibers $(\mu \mathrm{m})$} \\
\hline Theoretical & \multicolumn{6}{|c|}{510} \\
\hline Experimental & $462( \pm 54)$ & $480( \pm 68.4)$ & $480( \pm 7.3)$ & $474( \pm 14.9)$ & $481( \pm 46.1)$ & $475( \pm 8)$ \\
\hline \multicolumn{7}{|c|}{ Layer thickness ( $\mu \mathrm{m})$} \\
\hline Theoretical & \multicolumn{6}{|c|}{190} \\
\hline Experimental & $202.0( \pm 19.8)$ & $193.3( \pm 23.5)$ & $217.0( \pm 18.9)$ & $195.3( \pm 10.6)$ & $210.7( \pm 12.5)$ & $206.1( \pm 16.0)$ \\
\hline
\end{tabular}

reaction with chemiluminescence reagents (CDP-Star). All analyses were conducted in triplicates.

Polymerase chain reaction. For gene expression analysis, the scaffolds were taken from the media, washed twice with phosphate-buffered saline, cut into small pieces, and placed in an Eppendorf tube containing $700 \mu \mathrm{L}$ of TRIzol ${ }^{\circledR}$ (Invitrogen) and stored at $-80^{\circ} \mathrm{C}$. RNA isolation was performed by using a Bioke RNA II nucleospin RNA isolation kit (Makerey-Nagel). $150 \mu \mathrm{L}$ of $\mathrm{CHCl}_{3}$ was added, and the vials were vigorously mixed, followed by a centrifugation at $12,000 \mathrm{~g}$ for $15 \mathrm{~min}$ at $4^{\circ} \mathrm{C}$. The aqueous phase was transferred into a new tube, and an equal amount of $70 \%$ ethanol was added. The mixture was transferred into a filter column from the kit, and the extraction was carried on by following the manufacturer's protocol. RNA concentration and purity were evaluated via an ND1000 spectrophotometer (Nanodrop Technologies, Wilmington, DE); cDNA was synthesized using iScript ${ }^{\mathrm{TM}}$ (Bio-Rad, Hercules, CA) according to manufacturer's protocol. Quantitative polymerase chain reaction (PCR) was performed on the obtained cDNA by using the iQ SYBR $^{\circledR}$ Gree Sipermix (Bio-Rad) and the primers (gene B2M: forward primer ACAAAGTCACATGGTTCACA, reverse primer GACTTGTCTTTCAGCAAGGA; gene ALP: forward primer ACA AGCACTCCCACTTCATC, reverse primer TTCAGCTCGTACTGC ATGTC; gene Runx2: forward primer TGGTTACTGTCATGG CGGGTA, reverse primer TCTCAGATCGTTGAACCTTGCTA; gene Osteocalcin: forward primer TGAGAGCCCTCACACTCC TC, reverse primer CGCCTGGGTCTCTTCACTAC). PCR reaction was carried out on the MyiQ2 Two-Color Real-Time PCR Detection System (Bio-Rad) under the following conditions: the cDNa was denatured for $10 \mathrm{~min}$ at $95^{\circ} \mathrm{C}$, followed by 45 cycles, consisting of $15 \mathrm{~s}$ at $95^{\circ} \mathrm{C}, 15 \mathrm{~s}$ at $60^{\circ} \mathrm{C}$, and $15 \mathrm{~s}$ at $72^{\circ} \mathrm{C}$. A melting curve was generated from each reaction to test the presence of primer dimers and unspecific product. The cycle threshold was calculated by the BioRad iQ5 optical system software, in which the threshold was set in the lower log-linear region of the fluorescent signal. Ct values were normalized by the B2M housekeeping gene and $\Delta \mathrm{Ct}$ ((average of $\mathrm{Ct}$ control) - Ct value). Results were expressed as fold induction in mRNA expression normalized to the gene expression of the lay down pattern $0^{\circ} \%$ $75^{\circ} / 150^{\circ}$ scaffold cultured in basic medium.
Morphology of cells. The morphology of the cells on the PCL scaffolds was performed after 8 and 35 days of in vitro culture $(n=2)$. Cells-scaffolds constructs were fixed with $10 \%$ formalin for $30 \mathrm{~min}$, followed by rinsing three times with phosphate-buffered saline and dehydration with increasing concentrations of ethanol $(50,70,80,90,96$, and $100 \%)$ for 30 min each. Finally, all specimens were treated with hexamethyldisilazane (Sigma-Aldrich) and kept at room temperature overnight for air-drying. The morphology of the cells was observed under SEM (XL30 ESEM-FEG, Philips) after gold sputtering (Carringdon).

\section{Statistical analysis}

All quantitative experiments, including mechanical and biological tests, were carried out at least thrice and quantitative values are expressed as mean \pm standard deviation. Statistical analysis was carried out using one-way analysis of variance followed by a Tukey-Kramer test using KyPlot v.2.0 software (KyensLab, Tokyo, Japan). Values of $p \leq 0.05$ were considered statistically significant.

\section{RESULTS}

\section{Scaffolds characterization}

FDM is a simple and facile technique for the fabrication of oriented microfibrous structures with high porosity and high surface area to volume ratio, which is desirable in TE applications. ${ }^{10,15,25-27,30-34}$ In this study, PCL was used to produce such scaffolds. SEM images of the obtained PCL scaffolds revealed the internal architecture and pore shape of the constructs showing a clear influence of the angle deposition of successive fiber layers. The average fiber diameters and distance between the fibers measured for all six kind of architectures are shown in Table I. The fiber diameter, fiber spacing, and layer thickness did not change significantly among the different scaffold architectures. The geometry $90^{\circ} / 180^{\circ}$ was characterized with the most regular shape of pores between all analyzed architectures. Moreover, in this geometry the pores connect to each other axially, which makes them open throughout the whole scaffold. A similar pore arrangement was found for the fiber angle geometry of $0^{\circ} / 60^{\circ} / 120^{\circ}$. The numbers of pores and fibers connections between the layers were higher for geometries $90^{\circ}, 75^{\circ}$, and $60^{\circ}$ than for the remaining geometries. A different geometry was noticed for the architecture $0^{\circ} / 15^{\circ} / 30^{\circ}$, where the pores 
a)
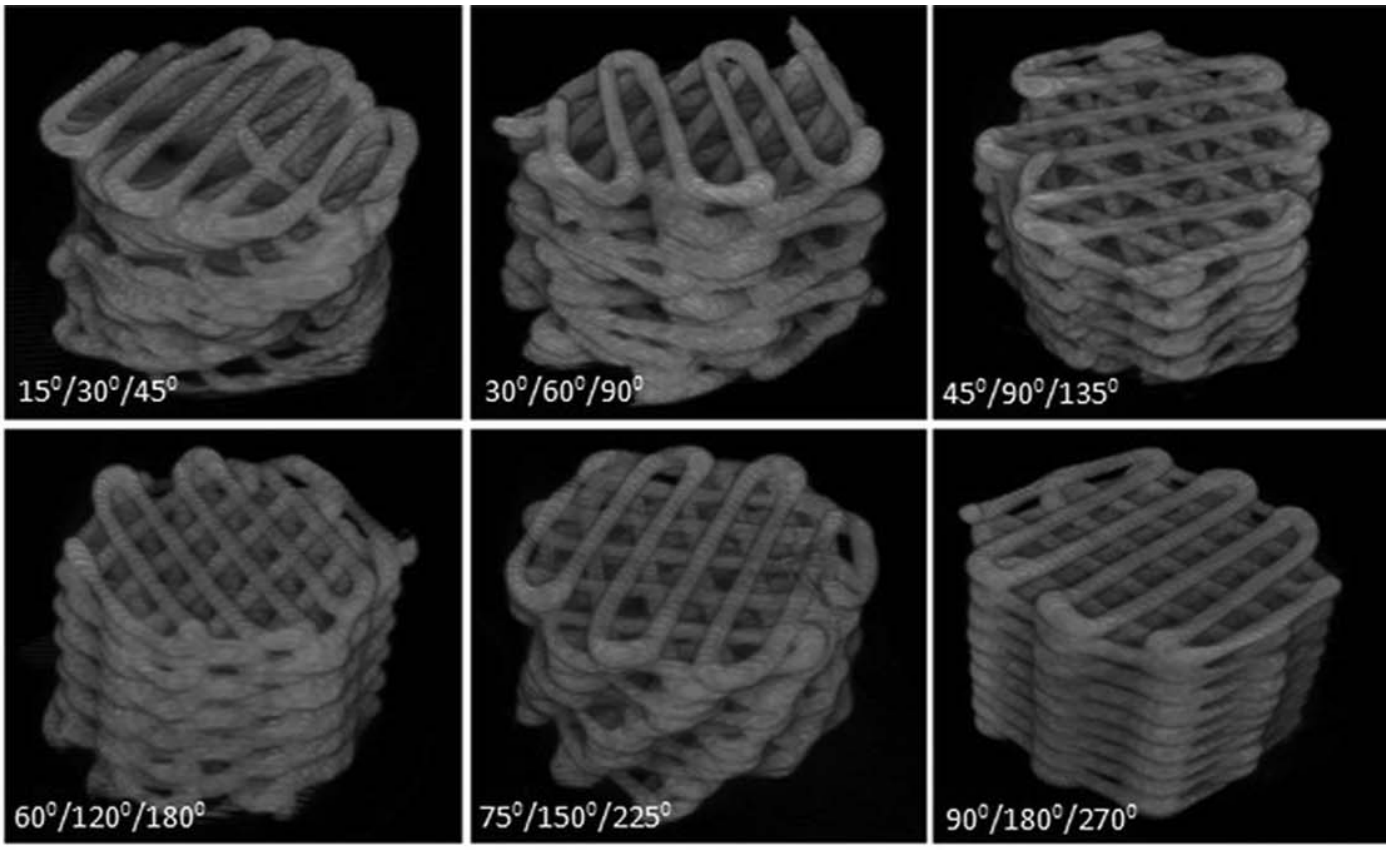

b)
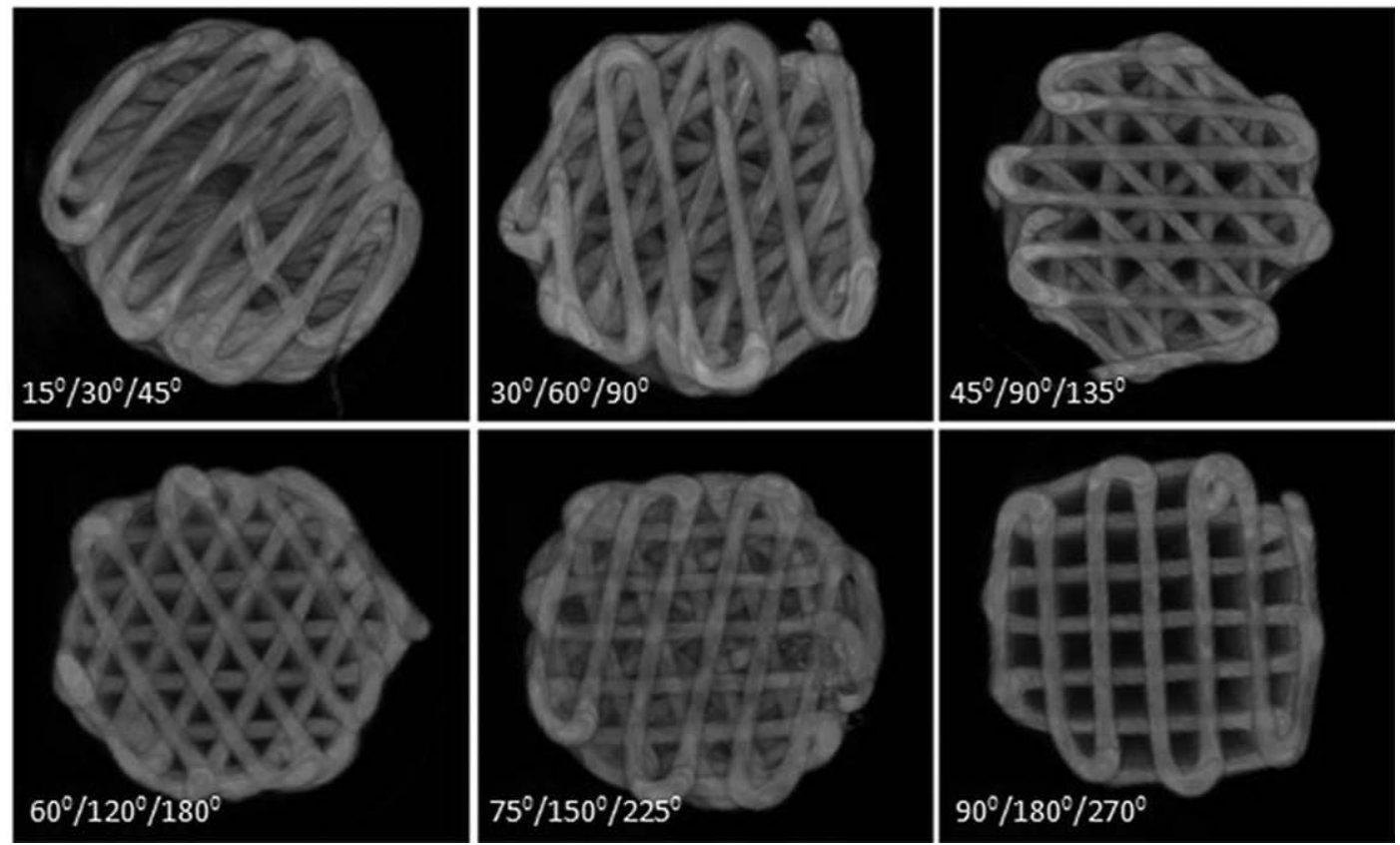

FIGURE 2. $\mu C T$ images of PCL scaffolds with different lay-down patterns. Side view (a); top view (b).

were not regular and arranged as a ladder-like helicoid structure. These significant differences in the samples architecture were clearly seen also by $\mu \mathrm{CT}$ images (Fig. 2). The scaffolds with lay down pattern $90^{\circ}, 75^{\circ}, 60^{\circ}$, and $45^{\circ}$ were characterized with more regular arrangements of fibers between the layers. Geometries with fiber angle deposition of $15^{\circ}$ and $30^{\circ}$ displayed irregular layers connections.

The scaffolds porosity were calculated $(n=3)$ based on $\mu \mathrm{CT}$ measurements (Table II). The theoretical porosity was also calculated by using Eq. (1). The differences between theoretical and experimental porosities were small. The average value of porosity for all scaffolds geometries was about $60 \%$.
All scaffolds were characterized by open interconnected porosity (Fig. 2). The surface area of the different scaffold's architecture was also calculated (Fig. 3). The highest surface area was obtained for the samples with $75^{\circ}$ angle deposition. For the other scaffold architectures, the surface area was on the same level. Moreover, the samples' volume has been measured, resulting in a comparable surface to volume ratio between samples.

\section{Mechanical properties}

It has to be noted that the macroporous structure influences the properties of the whole scaffold. ${ }^{22,24}$ Mechanical 
TABLE II. Scaffolds porosity calculations, experimental (from $\mu \mathrm{CT}$ measurements) and theoretical (from eq. 1)

\begin{tabular}{|c|c|c|c|c|c|c|}
\hline & \multicolumn{6}{|c|}{ Angle Deposition } \\
\hline & $15^{\circ} / 30^{\circ}$ & $30^{\circ} / 60^{\circ}$ & $45^{\circ} / 90^{\circ}$ & $60^{\circ} / 120^{\circ}$ & $75^{\circ} / 150^{\circ}$ & $90^{\circ} / 180^{\circ}$ \\
\hline \multicolumn{7}{|l|}{ Porosity (\%) } \\
\hline Experimental & 57 & 61 & 62 & 54 & 57 & 61 \\
\hline Theoretical & 64 & 63 & 60 & 60 & 53 & 52 \\
\hline
\end{tabular}

properties of the 3D constructs were characterized by static compression tests and dynamic mechanical analysis (DMA) studies (rotational rheometer). Mechanical strength analysis via compressive tests showed that specimens underwent a linear elastic deformation, followed by a linear plastic region which is typical of a compressive stress-strain curve. ${ }^{21}$ Static compression test and dynamic twisting of the specimen allowed to determine the comparable elastic modulus $(E)$ and dynamic stiffness $\left(E^{\prime}\right)$, respectively, in Figure 4. The highest $E$ was obtained for samples with a layer orientation of $90^{\circ}$, which was $50.4 \pm 6.3 \mathrm{MPa}$ (Fig. 4). Samples with $60^{\circ}$ and $45^{\circ}$ deposition angle were also characterized by a high comparable elastic modulus $40.8 \pm 2.1 \mathrm{MPa}$ and $31.9 \pm 3.9$ $\mathrm{MPa}$, respectively. The rest of the samples had modulus lower than $29 \mathrm{MPa}$, likely due to a smaller number of fiber connections between layers. A similar trend was also observed for the shear storage modulus, where the samples with $60^{\circ}$ deposition angle had the highest stiffness. However, the smallest storage modulus was observed for the architecture $90^{\circ}$. With changing the scaffold architecture, the dynamic stiffness varied from $5.12 \pm 0.02 \mathrm{MPa}$ for $0^{\circ} \%$ $90^{\circ}$ to $18.4 \pm 0.1 \mathrm{MPa}$ for $0^{\circ} / 60^{\circ}$.

\section{Cell culture}

Seeding efficiency results revealed that the amount of DNA on the samples with fiber orientation $0^{\circ} / 15^{\circ}$ was significantly higher at day 1 compared with the rest of the samples [Fig. 5(a)]. The cell number after 8 and 35 days of incubation are shown in Figure 5(b) and Figure 5(c), respectively. After 8 days of culture, the cell number increased with increasing angle deposition in each medium. After 35 days of culture, a significant difference was noticed for samples with internal orientation $0^{\circ} / 60^{\circ}$ where the highest cell number in basic and mineralization media was noticed. The amount of DNA in the constructs was the highest in basic medium for all kinds of scaffolds. Interestingly, after 8 days the ALP activity of culture did not show any significant differences in any architectures in mineralization medium (Fig. 6). However, after 35 days of culture, significant differences were noticed for the orientations $0^{\circ} / 15^{\circ}$ compared with the rest of the samples. Furthermore, the ALP activity was significantly higher for $0^{\circ} / 15^{\circ}$ than for the orientation $0^{\circ} / 60^{\circ}$. The PCR results confirmed what highlighted by previous tests (Fig. 7). As expected, culturing the hMSCs in mineralization media increased the expression of ALP genes, whereas osteocalcin and transcription factor runx2 expression levels were more mildly increased. Among the different pore geometries, no significant differences were observed in the three genes. Only runx2 seemed to be expressed more in the geometry with $15^{\circ}$ compared with the $0^{\circ} / 75^{\circ}$ and $0^{\circ} / 90^{\circ}$ orientations. In basic medium, no upregulation of the chosen pool of osteogenic genes was observed.

Additionally, as observed by SEM, the formed ECM filled the pores in all types of internal architectures and in all media (Fig. 8). After 1 day under differentiation condition, the cells formed a confluent layer on the scaffold bars. Subsequently, after 28 days in differentiation media, the cells produced a more pronounced layer of ECM that covered all the scaffolds' pores.

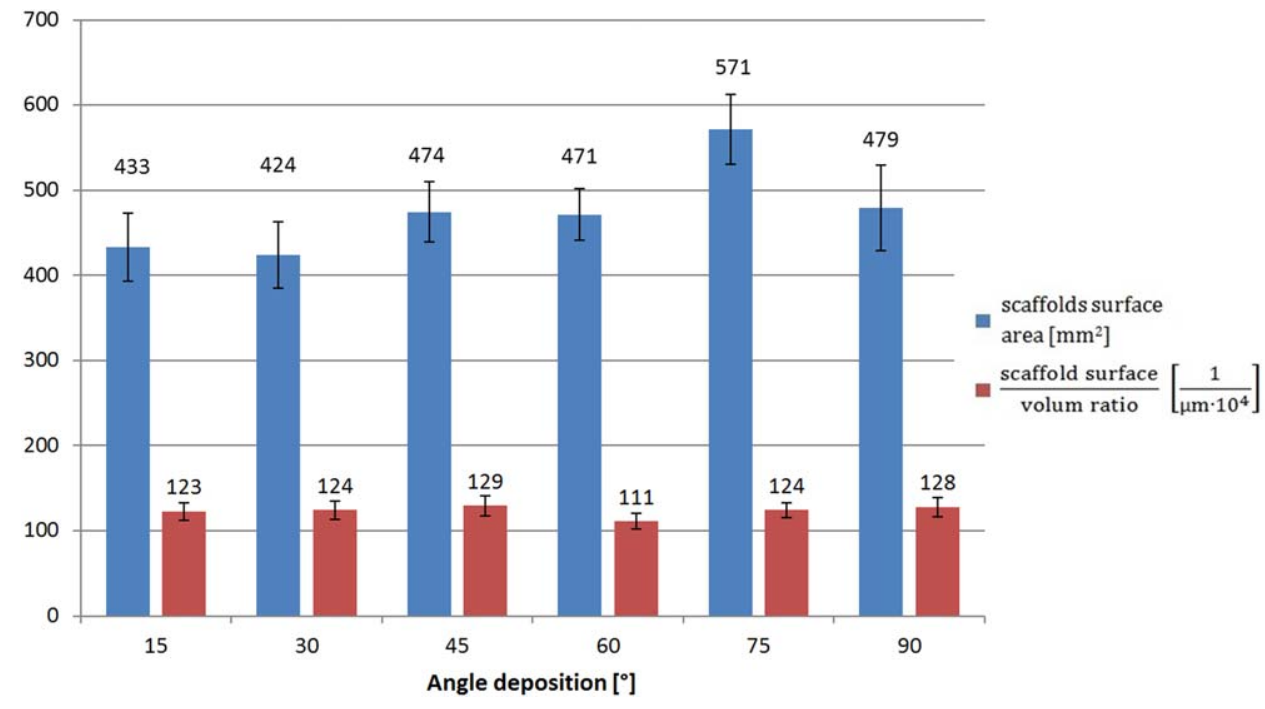

FIGURE 3. Scaffolds area surfaces and surface to volume ratio assessed on $\mu$ CT measurements. 

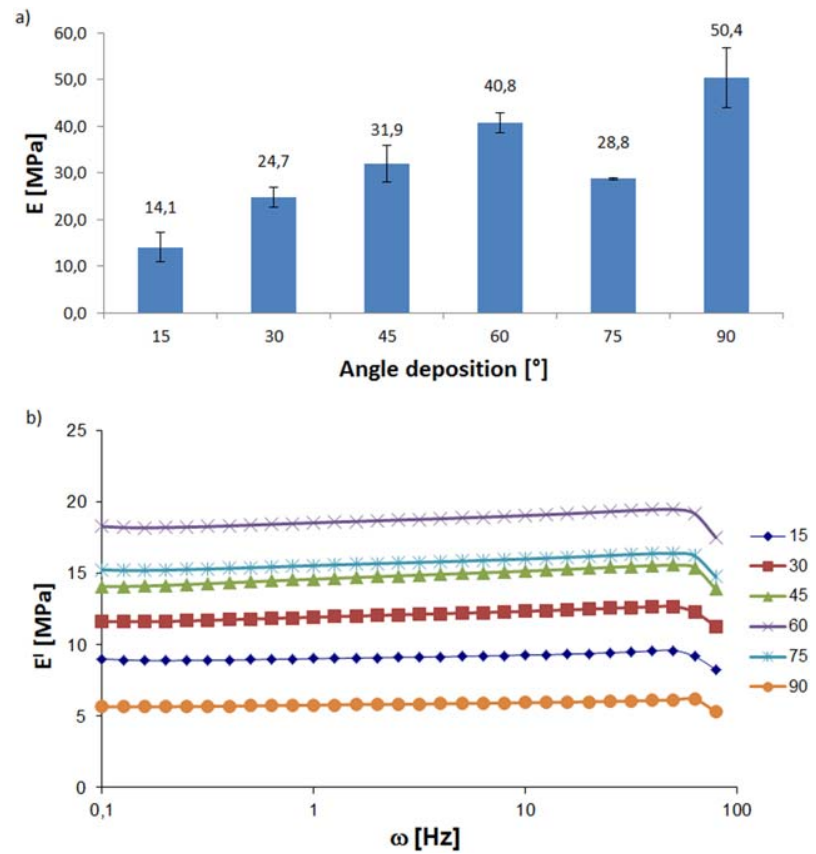

FIGURE 4. Calculations of (a) comparable elastic modulus $(E)$ and (b) shear storage modulus $\left(E^{\prime}\right)$.

\section{DISCUSSION}

Application of hMSCs with a biomaterial-based scaffold is a well-established concept for prospective therapies of bone defects. However, despite numerous preclinical studies and several medical experiments performed in this field throughout the last years, a routine therapy utilizing tissueengineered bone grafts has not been established so far. ${ }^{35}$ Polymeric scaffolds have several advantages over metal or ceramic scaffolds. Currently used polymers, especially PCL, are slowly biodegradable, can be shaped freely with FDM technology, and are less brittle than ceramics. ${ }^{36-39}$

In this study, the influence of pore shape on the mechanical and biological properties of 3D fiber deposited PCL scaffolds has been investigated. Bone tissue was also studied as a reference to show how 3D scaffolds can mimic a natural tissue. First, SEM analysis revealed a very good consistency between the machine settings and the actual parameters. Variations of fiber diameter, fiber spacing, and layer thickness were constant for all analyzed constructs. These results were also confirmed by $\mu \mathrm{CT}$ investigation. Additionally, $\mu \mathrm{CT}$ analysis did not show delamination in the constructs. Scaffolds presented 100\% interconnected pores and were reproducible with the same characteristics each time they were processed. Measured porosity showed a porosity ranging from $57 \%$ to $62 \%$. All scaffolds were characterized by open interconnected porosity (Fig. 2), which is required for tissue constructs. The obtained porosity level is a good compromise between mechanical and biological properties. $^{22}$ High porosity and pore size of $480 \mu \mathrm{m}$ are known to result in greater bone ingrowth. ${ }^{40}$ Porosity and pore architecture play a significant role on cell survival, proliferation, and migration, resulting in ECM formation. ${ }^{40,41}$ Pore interconnectivity allows for cell ingrowth, vasculariza- tion, and nutrient diffusion for cell survival. ${ }^{42-44}$ The extent of ECM secretion also increases by increasing the pore size. ${ }^{41}$ It was found that in scaffolds with smaller pores, the tendency was tilted toward cell growth rather than ECM secretion, ${ }^{41}$ resulting in over confluence during the middle and late stages of differentiation; consequently, the extent of ECM secretion decreased compared with scaffolds with larger pores. ${ }^{45}$ However, high porosity resulted also in diminished mechanical properties, thereby setting an upper functional limit for pore size and porosity is required. ${ }^{22}$ Moreover, to get good fusion between layers, the pore size in the $\mathrm{Z}$ direction is compromised. Thus, a balance must be reached depending on the tissue to be repaired. FDM constructs were mechanically characterized through static compression test and DMA for different geometrical and architectural configurations. From a mechanical point of view, these scaffolds were treated and analyzed following a solid-state mechanics approach. However, it has to be noted that the macroporous structure plays a determinant role on

a)

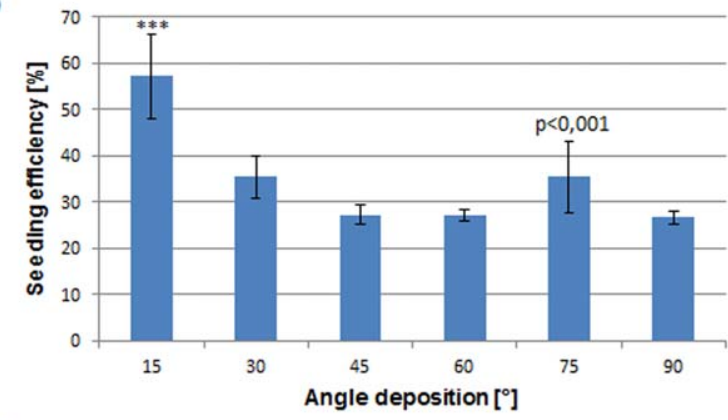

b)

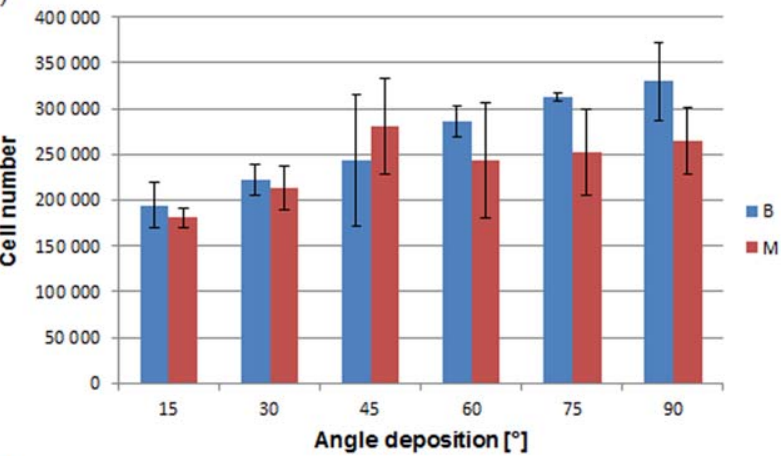

c)

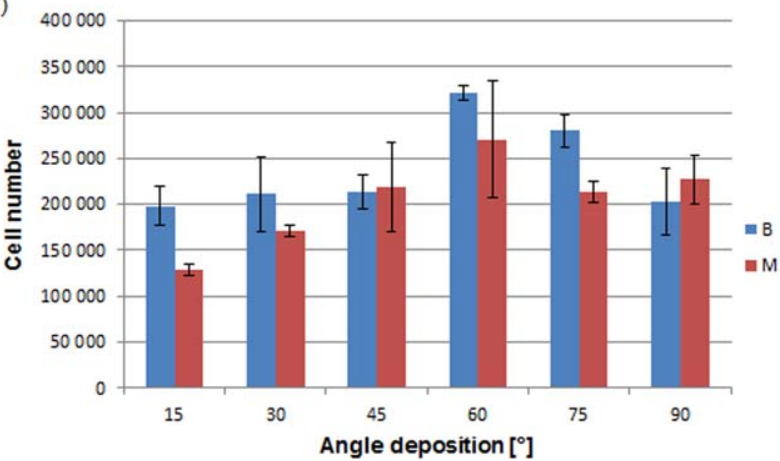

FIGURE 5. Effect of angle deposition on seeding efficiency at day 1 (a) and cell number after (b) 8 and (c) 35 days of culture. 

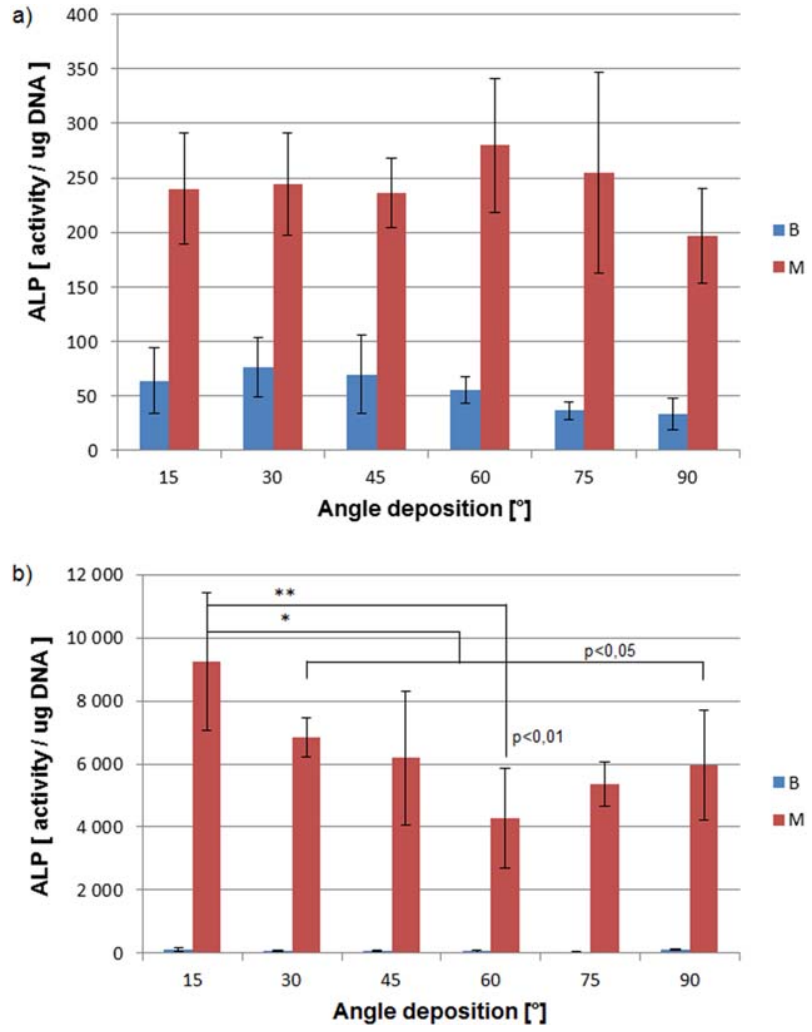

FIGURE 6. ALP activity after 1 (a) and 28 (b) days under differentiation conditions. the properties of the whole scaffold. It is, indeed, the organization and the volume of macropores that drive the modulation of mechanical properties from the bulk material. Compression tests and DMA were used to determine the constructs' comparable elastic modulus $(E)$ and storage modulus $\left(E^{\prime}\right)$ behavior, respectively. The highest comparable elastic modulus was observed for the orientations $0^{\circ} / 90^{\circ}$ and $0^{\circ} / 60^{\circ}$. However, DMA tests showed that for $0^{\circ} / 90^{\circ}$ constructs the storage modulus was the lowest in all analyzed samples, whereas the highest result was noticed for a $0^{\circ} / 60^{\circ}$ configuration. The $0^{\circ} / 90^{\circ}$ orientation showed a less elastic behavior compared with the other scaffolds during dynamic tests [Fig. 4(b)]. The difference between mechanical strength testing during static and dynamic tests is likely the result of mounting the samples within a testing machine. During compression test connection of the fibers are compressed vertically. During DMA test a rotational rheometer is used to twist the sample. The observed trends could be directly related to the fibers connection between each layer in a scaffold. As observed by SEM and $\mu \mathrm{CT}$, the pore number and size in a single layer are strictly correlated with the angle of deposition (Table I). In fact, a decrease in pore number in a single layer results in a decrease in the number of connections between the fibers and, consequently, could lead to a decrease in scaffold's stiffness. However, results of dynamical tests showed that the shape of the fibers' connection could be also an important factor in determining the overall mechanical properties

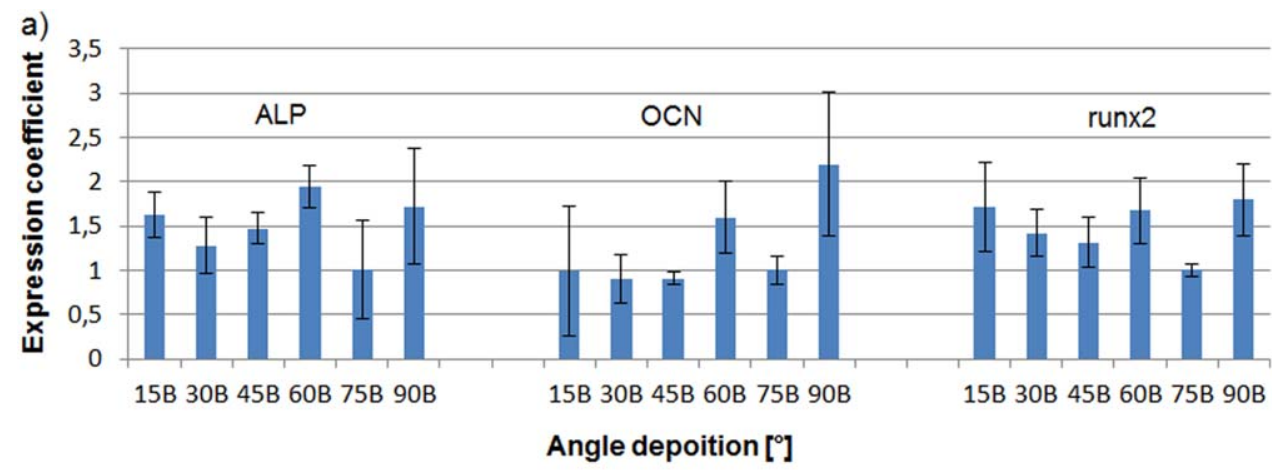

b)

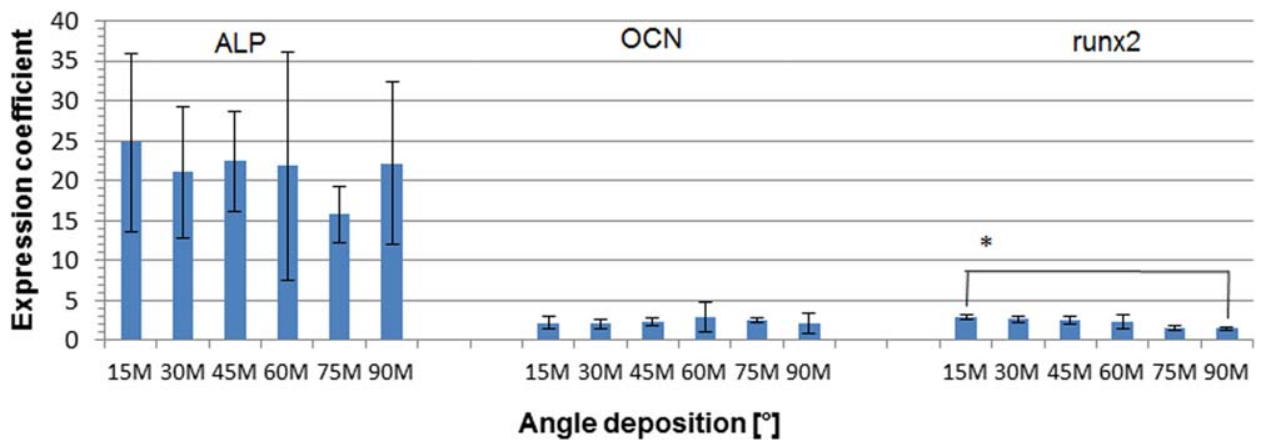

FIGURE 7. Alkaline phosphatase (ALP), osteocalcin (OCN), and runx2 gene expression levels in the basic (a) and mineralization (b) medium after 28 days under differentiation conditions. 


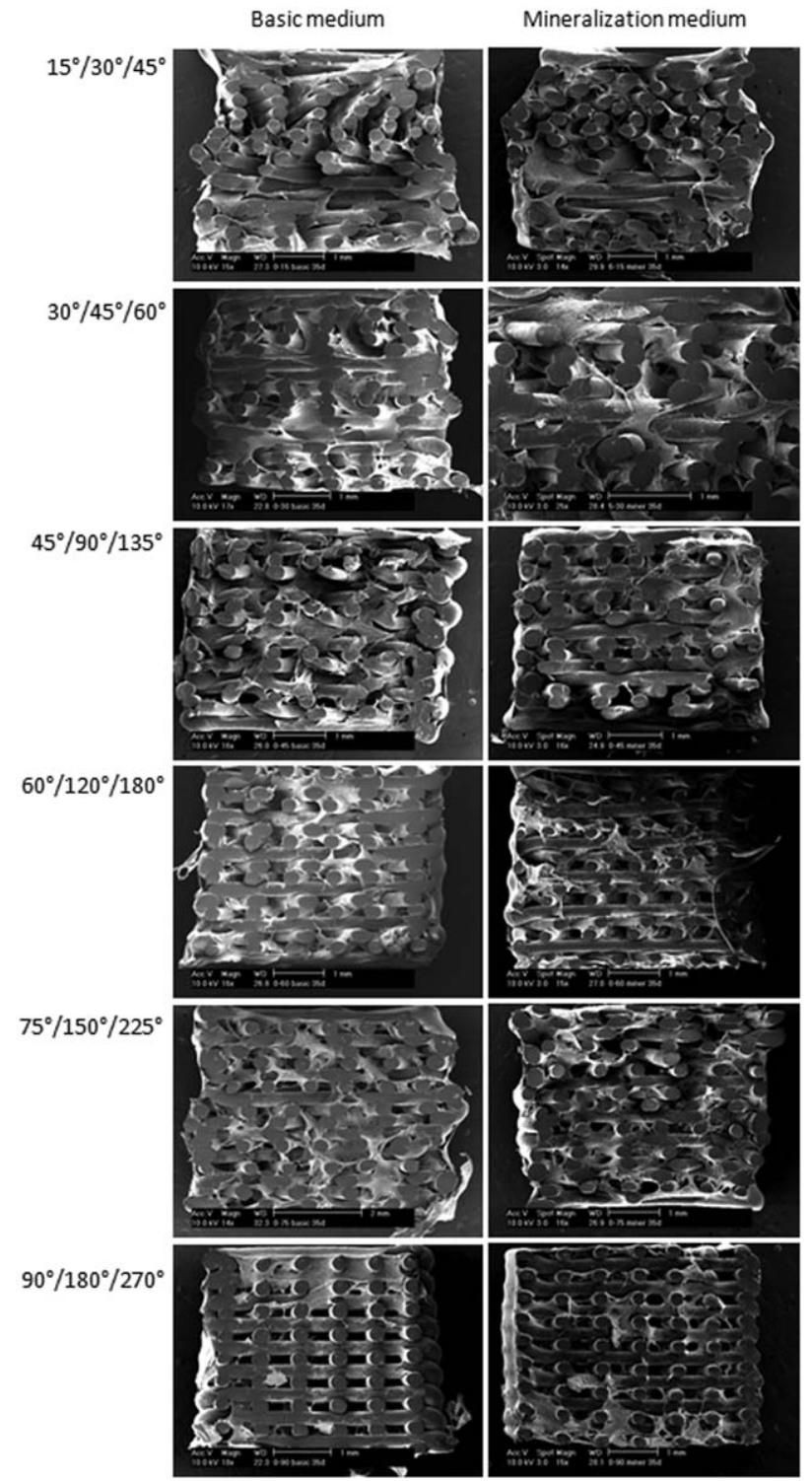

FIGURE 8. SEM images of investigated scaffolds after 35 days of incubation.

of the scaffolds. With a $0^{\circ} / 90^{\circ}$ orientation, fibers connections have a square shape, which is associated to a low shear storage modulus. If the fibers connection has a more and more rhombic shape, the shear storage modulus increased. Comparing these two mechanical tests, we can conclude that $0^{\circ} / 60^{\circ}$ orientation has the best mechanical parameters among the all analyzed architectures for bone regeneration. This layer orientation is also often used in medical treatment of bone disease. ${ }^{37,38,46,47}$ In this study, apparent compression modulus was estimated from the initial linear region of the stress-strain curves following ASTM standard D1621-04a. This allows to compare the obtained results with previous studies presenting mechanical properties of PCL scaffolds. ${ }^{21,28,29}$ This method of estimation of the Young's modulus assumes that 3D constructs behave purely elastically. However, the loaded porous polymeric scaffold might undergo elastic as well as plastic deformations during quasi-static loading, and then, the Young's modulus could be better determined from the unloading part of stress-strain curve. $^{22}$ Therefore, in future studies, the quasi-static unloading tests should be considered to provide the Young's modulus of PCL scaffolds.

It should be noticed that before mechanical testing, all samples were sterilized by gamma-irradiation using a standard sterilization dose of $25 \mathrm{kGy}$. The irradiation process can influence the molecular weight as well as the mechanical properties of the treated PCL scaffolds. The gammairradiation causes breakage of the polymer chains, which further results in reduction of number average molecular weight $\left(M_{\mathrm{n}}\right)$. However, the same irradiation cross-links the chains increasing weight average molecular weight $\left(M_{\mathrm{w}}\right)$. Increase of $M_{\mathrm{w}}$ might result in increase of stiffness and strength of the polymer. ${ }^{48,49}$

Scaffold with high open interconnected porous network stimulates and supports bone ingrowth as well as subsequent remodeling and maturation by providing optimal stiffness and external and internal geometrical shapes. ${ }^{37,40}$ The cell study showed that pore shape and size play a significant role for seeding efficiency and proliferation. After $8 \mathrm{~h}$, the highest cell numbers were observed for the $0^{\circ} / 15^{\circ}$ orientation, but during increasing incubation time the trend was changed (Fig. 5). The tortuous pore network of the $0^{\circ} / 15^{\circ}$ geometry had probably ensured the entrapment of part of nonattached cells, displaying a higher cell seeding efficiency. With further media changes, this excess of cells was washed out. After 1 day under differentiation conditions, cell number displayed a lower number in scaffolds with geometry $0^{\circ}-30^{\circ}$ and $0^{\circ}-15^{\circ}$ with respect to the other geometries. After 35 days, the architecture $0^{\circ} / 60^{\circ}$ displayed the highest cell number. The ALP activity assay did not show relevant differences between investigated scaffolds after 1 day under mineralization conditions. The orientation $0^{\circ}-15^{\circ}$ displayed significantly higher ALP activity level with respect to the other construct after 28 days under mineralization conditions especially to the orientation $0^{\circ} / 60^{\circ}$. The protein analysis results were supported by the quantitative PCR analysis. It is known that the addition of dexamethasone to the culture media greatly enhances the ALP; therefore, its expression showed higher induction levels in all the constructs when compared with runx2 and osteocalcin expression. Among the different pore geometries, no significant differences were observed in the three genes. Only runx 2 seemed to be significantly highly expressed in the geometry with $15^{\circ}$ compared with the $0^{\circ} / 75^{\circ} / 150^{\circ}$ and $0^{\circ} / 90^{\circ} / 180^{\circ}$ orientations. In basic medium, all the genes were not upregulated.

In literature, orientations of $60^{\circ}$ and $45^{\circ}$ are the most commonly used. ${ }^{35-37,46}$ For bone tissue engineering, scaffolds must provide sufficient initial mechanical strength and stiffness to substitute for the loss of mechanical function of the diseased, damaged, or missing tissue. ${ }^{46}$ In our study, we showed that from a mechanical point of view the $0^{\circ} / 60^{\circ}$ orientation seems to be the best scaffold architecture option among those tested for bone regeneration. From a biological point of view, our studies showed only slight differences in 
the differentiation of hMSCs on the PCL constructs with different lay down patterns. The internal architecture of the fabricated scaffolds seemed to significantly influence cell adhesion and proliferation. Bone tissue ingrowth and maturation differ temporally from tissue to tissue and is strictly related with pore interconnections and pore size larger than $400 \mu \mathrm{m} .{ }^{46}$ In our studies, all scaffolds were characterized with open interconnected porous network with pore size ranging from $460 \mu \mathrm{m}\left(0^{\circ} / 15^{\circ}\right)$ to $480 \mu \mathrm{m}\left(0^{\circ} / 60^{\circ}\right)$, which makes these scaffolds useful possible implants for bone tissue regeneration.

\section{CONCLUSION}

This study shows how the internal architecture of 3D fiber deposited scaffolds could be modulated to accomplish mechanical and biological requirements for bone regeneration applications. The scaffold architecture is relevant from a mechanical and biological point of view. Different pore shapes showed to influence both static and dynamic mechanical properties of fabricated scaffolds, as well as cell attachment, ingrowth, and early osteogenic differentiation.

\section{REFERENCES}

1. Hutmacher DW. Scaffold design and fabrication technologies for engineering tissues-State of the art and future perspectives. J Biomater Sci Polym Ed 2001;12:107-124.

2. Landers R, Pfister A, Hübner $U$, John $H$, Schmelzeisen R, Mülhaupt R. Fabrication of soft tissue engineering scaffolds by means of rapid prototyping techniques. J Mater Sci 2002;37:31073116.

3. Kweon H, Yoo MK, Park IK, Kim TH, Lee HC, Lee HS, Oh JS, Akaike T, Cho CS. A novel degradable polycaprolactone networks for tissue engineering. Biomaterials 2003;24:801-808.

4. Charles-Harris M, Koch MA, Navarro M, Lacroix D, Engel E, Planell JA. A PLA/calcium phosphate degradable composite material for bone tissue engineering: an in vitro study. J Mater Sci Mater Med 2008;19:1503-1513.

5. Lam CX, Hutmacher DW, Schantz JT, Woodruffm MA, Teoh SH. Evaluation of polycaprolactone scaffold degradation for 6 months in vitro and in vivo. J Biomed Mater Res A 2009;90:906-919.

6. Nair LS, Laurencin CT. Polymers as biomaterials for tissue engineering and controlled drug delivery. Adv Biochem Eng Biotechnol 2006;102:47-90.

7. Rezwan K, Chen QZ, Blaker JJ, Boccaccini AR. Biodegradable and bioactive porous polymer/inorganic composite scaffolds for bone tissue engineering. Biomaterials 2006;27:3413-3431.

8. Sun Y, Finne-Wistrand A, Albertsson AC, Xing Z, Mustafa K, Hendrikson WJ, Grijpma DW, Moroni L. Degradable amorphous scaffolds with enhanced mechanical properties and homogeneous cell distribution produced by a three-dimensional fiber deposition method. J Biomed Mater Res A 2012;100:2739-2749.

9. Kim TK, Sharma B, Williams CG, Ruffner MA, Malik A, McFarland $E G$, Elisseeff JH. Experimental model for cartilage tissue engineering to regenerate the zonal organization of articular cartilage. Osteoarthritis Cartilage 2003;11:653-664.

10. Sachlos E, Czernuszka JT. Making tissue engineering scaffolds work. Review: The application of solid freeform fabrication technology to the production of tissue engineering scaffolds. Eur Cell Mater 2003;5:29-39; discussion 39-40.

11. Lin CY, Kikuchi N, Hollister SJ. A novel method for biomaterial scaffold internal architecture design to match bone elastic properties with desired porosity. J Biomech 2004;37:623-636.

12. Liu X, Ma PX. Polymeric scaffolds for bone tissue engineering. Ann Biomed Eng 2004;32:477-486.

13. Vozzi G, Previti A, De Rossi D, Ahluwalia A. Microsyringe-based deposition of two-dimensional and three-dimensional polymer scaffolds with a well-defined geometry for application to tissue engineering. Tissue Eng 2002;8:1089-1098.

14. Zhou H, Lawrence JG, Bhaduri SB. Fabrication aspects of PLACaP/PLGA-CaP composites for orthopedic applications: A review. Acta Biomater 2012;8:1999-2016.

15. Zein I, Hutmacher DW, Tan KC, Teoh SH. Fused deposition modeling of novel scaffold architectures for tissue engineering applications. Biomaterials 2002;23:1169-1185.

16. Yeong WY, Chua CK, Leong KF, Chandrasekaran M. Rapid prototyping in tissue engineering: Challenges and potential. Trends Biotechnol 2004;22:643-652.

17. Hamid Q, Snyder J, Wang C, Timmer M, Hammer J, Guceri S, Sun W. Fabrication of three-dimensional scaffolds using precision extrusion deposition with an assisted cooling device. Biofabrication 2011;3:034109.

18. Wohlers T. Wohlers Report 2000. Fort Collins, CO: Wohlers Associates, Inc.; 2000.

19. Sharma B, Elisseeff JH. Engineering structurally organized cartilage and bone tissues. Ann Biomed Eng 2004;32:148-159.

20. Grayson WL, Bhumiratana S, Grace Chao PH, Hung CT, VunjakNovakovic G. Spatial regulation of human mesenchymal stem cell differentiation in engineered osteochondral constructs: Effects of pre-differentiation, soluble factors and medium perfusion. Osteoarthritis Cartilage 2010;18:714-723.

21. Hutmacher DW, Schantz T, Zein I, Ng KW, Teoh SH, Tan KC. Mechanical properties and cell cultural response of polycaprolactone scaffolds designed and fabricated via fused deposition modeling. J Biomed Mater Res 2001;55:203-216.

22. Luczynski KW, Brynk T, Ostrowska B, Swieszkowski W, Reihsner $\mathrm{R}$, Hellmich C. Consistent quasistatic and acoustic elasticity determination of poly-l-lactide-based rapid-prototyped tissue engineering scaffolds. J Biomed Mater Res A 2013;101:138-144.

23. Martin I, Obradovic B, Treppo S, Grodzinsky AJ, Langer R, Freed LE, Vunjak-Novakovic G. Modulation of the mechanical properties of tissue engineered cartilage. Biorheology 2000;37:141-147.

24. Moroni L, de Wijn JR, van Blitterswijk CA. 3D fiber-deposited scaffolds for tissue engineering: influence of pores geometry and architecture on dynamic mechanical properties. Biomaterials 2006;27:974-985.

25. Sila-Asna M, Bunyaratvej A, Maeda S, Kitaguchi $H$, Bunyaratavej N. Osteoblast differentiation and bone formation gene expression in strontium-inducing bone marrow mesenchymal stem cell. Kobe J Med Sci 2007;53:25-35.

26. Sittinger M, Hutmacher DW, Risbud MV. Current strategies for cell delivery in cartilage and bone regeneration. Curr Opin Biotechnol 2004;15:411-418.

27. Liu YF, Zhu FD, Dong XT, Peng W. Digital design of scaffold for mandibular defect repair based on tissue engineering. J Zhejiang Univ Sci B 2011;12:769-779.

28. Domingos M, Intranuovo F, Gloria A, Gristina R, Ambrosio L, Bartolo PJ, Favia P. Improved osteoblast cell affinity on plasmamodified 3-D extruded PCL scaffolds. Acta Biomater 2013;9:59976005.

29. Rodenas-Rochina J, Ribelles JL, Lebourg M. Comparative study of PCL-HAp and PCL-bioglass composite scaffolds for bone tissue engineering. J Mater Sci Mater Med 2013;24:1293-1308.

30. Yang S, Leong KF, Du Z, Chua CK. The design of scaffolds for use in tissue engineering. Part II. Rapid prototyping techniques. Tissue Eng 2002;8:1-11.

31. Williams JM, Adewunmi A, Schek RM, Flanagan CL, Krebsbach $\mathrm{PH}$, Feinberg SE, Hollister SJ, Das S. Bone tissue engineering using polycaprolactone scaffolds fabricated via selective laser sintering. Biomaterials 2005;26:4817-4827.

32. Swieszkowski W, Tuan BHS, Kurzydlowski KJ, Hutmacher DW. Repair and regeneration of osteochondral defects in the articular joints. Biomol Eng 2007;24:489-495.

33. Mastrogiacomo M, Scaglione S, Martinetti R, Dolcini L, Beltrame F, Cancedda R, Quarto R. Role of scaffold internal structure on in vivo bone formation in macroporous calcium phosphate bioceramics. Biomaterials 2006;27:3230-3237.

34. Leong KF, Cheah CM, Chua CK. Solid freeform fabrication of three-dimensional scaffolds for engineering replacement tissues and organs. Biomaterials 2003;24:2363-2378. 
35. Zhang X, Li XW, Li JG, Sun XD. Preparation and mechanical property of a novel 3D porous magnesium scaffold for bone tissue engineering. Mater Sci Eng C Mater Biol Appl 2014;42:362367.

36. Choy DK, Nga VD, Lim J, Lu J, Chou N, Yeo TT, Teoh SH. Brain tissue interaction with three-dimensional, honeycomb polycaprolactone-based scaffolds designed for cranial reconstruction following traumatic brain injury. Tissue Eng Part A 2013;19: 2382-2389.

37. Holzapfel BM, Chhaya MP, Melchels FPW, Holzapfel NP, Prodinger PM, von Eisenhart-Rothe R, van Griensven M, Thorsten Schantz J, Rudert M, Hutmacher DW. Can bone tissue engineering contribute to therapy concepts after resection of musculoskeletal sarcoma? Sarcoma 2013;2013: Article ID 153640.

38. Probst FA, Hutmacher DW, Muller DF, Machens HG, Schantz JT. [Calvarial reconstruction by customized bioactive implant]. Handchir Mikrochir Plast Chir 2010;42:369-373.

39. Schantz JT, Machens HG, Schilling AF, Teoh SH. Regenerative medicine: Implications for craniofacial surgery. J Craniofac Surg 2012:23:530-536.

40. Mandal BB, Kundu SC. Cell proliferation and migration in silk fibroin 3D scaffolds. Biomaterials 2009;30:2956-2965.

41. Lien SM, Ko LY, Huang TJ. Effect of pore size on ECM secretion and cell growth in gelatin scaffold for articular cartilage tissue engineering. Acta Biomater 2009;5:670-679.
42. Roy TD, Simon JL, Ricci JL, Rekow ED, Thompson VP, Parsons JR. Performance of degradable composite bone repair products made via three-dimensional fabrication techniques. J Biomed Mater Res A 2003;66:283-291.

43. Kim HJ, Kim UJ, Vunjak-Novakovic G, Min BH, Kaplan DL. Influence of macroporous protein scaffolds on bone tissue engineering from bone marrow stem cells. Biomaterials 2005;26:4442-4452.

44. Griffon DJ, Sedighi MR, Schaeffer DV, Eurell JA, Johnson AL. Chitosan scaffolds: Interconnective pore size and cartilage engineering. Acta Biomater 2006;2:313-320.

45. Annabi N, Nichol JW, Zhong X, Ji C, Koshy S, Khademhosseini A, Dehghani F. Controlling the porosity and microarchitecture of hydrogels for tissue engineering. Tissue Eng Part B 2010;16:371-383.

46. Hutmacher DW, Cool S. Concepts of scaffold-based tissue engineering the rationale to use solid free-form fabrication techniques. J Cell Mol Med 2007;11:654-669.

47. Ho ST, Hutmacher DW. A comparison of micro CT with other techniques used in the characterization of scaffolds. Biomaterials 2006;27:1362-1376.

48. Cottam E, Hukins DW, Lee K, Hewitt C, Jenkins MJ. Effect of sterilisation by gamma irradiation on the ability of polycaprolactone (PCL) to act as a scaffold material. Med Eng Phys 2009;31:221226.

49. Walo M, Przybytniak G, Nowicki A, Świeszkowski W. Radiationinduced effects in gamma-irradiated PLLA and PCL at ambient and dry ice temperatures. J Appl Polym Sci 2011;122:375-383. 